\title{
MENJAGA EKSISTENSI BUDAYA LOKAL DENGAN PENDEKATAN KOMUNIKASI LINTAS BUDAYA
}

\author{
Juhanda \\ Prodi Perhotelan, FISIP Universitas Muhammadiyah Jember \\ Jl. Karimata No.49 Jember Kode Pos 69121 \\ Email: juhanda@akparmuhjember.ac.id
}

\begin{abstract}
The effect of globalism is the world view becoming the globe as a "global village. It is a small space and time covering "the global village" as a media to interact with people from other nations. People, with different culture and ideology, can communicate with others by implementing good relationship through economic, social, and cultural sectors, etc. Every nations has to be wise concerning with other culture in order to create mutual relationship. The effect of globalization forces people to choose: firstly is to imitate the effect of globalization, and secondly is to keep the local culture. If people can maintain and manage the local culture by protecting it, then the language, art, and various traditions and customs can develop the local culture naturally. Otherwise, if the local culture is not being maintained by the local people, the local culture will be slowly disappeared. By keeping the local culture, we have to look at the component of culture stated by Koentjaraningrat which consists of language, knowledge, job, art, the various traditions and customs. One of the cultural component is language. Local languages are used to maintain the local culture. In communication, language is used to transmit the message from sender to receiver. Cultural communication is used to understand other people with different culture. If the communication can be effective to fulfil the needs of similar culture, then the message can be understood by others. Understanding the local language is important, not only learning the language itself but also the culture of the people. To protect the local culture can be established by each individuals. They have to realize that they have responsiblity to keep the local culturealthough they live with various culture.
\end{abstract}

Keywords : communication, local culture, globalization

\begin{abstract}
ABSTRAK
Sisi terang, samar-samar, dan gelap globalisme telah dan sedang membanjiri sudut-sudut bumi manusia, yang kemudian dilabeli dengan 'desa buana' (global village). Konsekwensi logisnya adalah semua manusia dalam lintas budaya, ideologi, dan agama, terus menerus melakukan komunikasi secara lintas budaya pula. Budaya lokal, sebagai topik bahasan ini, secara sadar maupun tidak akan terus mengalami perubahan, baik dan buruk, seiring dengan dinamika budaya globalisme yang nyaris netral etis. Bahasa komunikasi, baik verbal maupun non-verbal merupakan alat komunikasi lintas budaya. Tujuh unsur kebudayaan oleh Koentjaraningrat akan selalu digunakan secara dinamis oleh kebudayaan lintas suku, agama, etnik, dan kepercayaan di penjuru buana ini. Penguatan dan pendidikan budaya, yakni gerakan literasi budaya, adalah suatu proses penguatan budaya lokal dalam dinamikanya dengan masyarakat di lingkup domestik maupun internasional.
\end{abstract}

Kata Kunci: komunikasi, budaya lokal, globalisme 


\section{PENDAHULUAN}

Globalisme hari ini menjadikan sudut-sudut dunia semakin sangat dekat dan bervariasi dalam kehidupan seharihari. Melalui teknologi komunikasi dan informasi nyaris semua dimensi dari sudut dunia manapun sangat mudah untuk kita ketahui. Akibatnya tanpa disadari difusi ide-ide dan gagasan, baik berupa isu isu sosial ataupun budaya dari luar dengan gampang masuk dan menyebar di masyarakat, kemudian terinternalisasi dalam sisi sisi kehidupan masyarakat suatu negara. Persebaran ide-ide dan gagasan tersebut makin intens menerobos semua deminsi sosial dengan frekuensi yang sangat cepat karena didukung oleh kemajuan teknologi informasi dan para penyedia informasi maya yang juga semakin mengganas. Pengaruh yang kompleks tersebut sudah dan sedang mempengaruhi kehidupan masyarakat/ bangsa suatu negara, tak terkecuali masyarakat dan bangsa Indonesia. Konsekwensi riil dari perkembangan globalisme yang masuk secara masif tersebut pada kenyataannya mempengaruhi budaya tempatan yang ada.

Pada saat pengaruh kuat dan masif globalisme masuk ke dalam budaya lokal, konsekuensinya masyarakat akan dihadapkan pada pilihan apakah akan mengikuti pengaruh globalisasi tersebut atau akan tetap kukuh memproteksi budaya yang sudah ada yang telah mentradisi. Manakala masyarakat lokal dengan segala kemampuan kearifannya berupaya memproteksi budaya lokal dengan kekuatan adat istiadat, norma, bahasa, kesenian dengan penuh kesadaran maka derasnya pengaruh budaya dari luar akan secara relatif dapat diadaptasikan. Sebaliknya, jika nilai nilai budaya lokal dipandang tidak perlu dihiraukan oleh masyarakat -kurang compatible atau out of date dengan progres peradaban majumaka masyarakat, cepat atau lambat, akan terpengaruh dengan budaya dari luar tersebut. Oleh karena itu, memahami makna budaya lokal yang baik, seperti kebersamaan, silaturahim, gotong-royong, saling percaya, dll., adalah sangat penting terutama dalam upaya untuk memahami karakteristik budaya setempat, perlu sikap saling menghargai dan menghormati budaya yang ada.

Pada saat menperbincangkan tentang karakter dan atau corak budayal kebudayaan, yang terbersit pada pikiran kita adalah bahwa ia berkaitan erat dengan suatu wilayah teritorial, misalnya budaya Amerika Latin, tentu pula kita berpikir tentang mempelajari budaya Amerika latin itu tentang kewilayahan yang meliputi, misalnya Meksiko, Brazil, Argentina, Uruguay, dan wilayah di sekitarnya. Namun, menurut Gerry Philipsen. 2008, hal. 269-280., seorang pakar komunikasi dari University of Washington, menyatakan bahwa mempelajari budaya tidak saja terkait dengan mengkaji wilayah atau letak geografis, suku, atau etnisnya, namun lebih dari itu adalah tentang pola perilaku, bahasa, adat istiadat yang melekat di dalam kehidupan masyarakatnya. Lebih jauh, budaya adalah sebuah konstruk sosial yang mengandung setumpuk nilai historis di dalamnya yang terimplementasikan melalui aturan, simbol, dan gagasan yang terpaut pada norma norma kehidupan di dalamnya. Adalah Griffin (dalam Roland Barthes, 2014) dalam tulisannya A First Look at Communication Theory telah menyatakan bahwa "culture is closely related to a process of expressing messages of a certain codes. Through communicating and comprehending a non-verbal forms of comunication implemented by someone, then the codes of culture may be relatively easy to understand".

Dalam berkomunikasi seseorang mampu meretas kekakuan, handicap, dan kegagapan budaya jika para partisipan yang terlibat di dalam komunikasi itu mempunyai latar belakang budaya yang sama. Sekedar mempermudah bahwa orang Jawa akan lebih lancar berkomunikasi dengan orang yang memahami bahasa Jawa ketimbang dengan 
seseorang yang berasal dari bahasa dan budaya asing. Dengan kata lain, perbedaan latar belakang budaya dan bahasa cenderung terkendala dalam berkomunikasi. Hal itu terjadi karena adanya perbedaan kebiasaan, nilai, norma budaya yang dipakai ketika komunikasi berlangsung. Dengan demikian, makna dari pesan yang diterima kemungkinan mendapatkan kendala besar dan tidak utuh, atau bahkan tidak dapat dipahami oleh komunikan. Banyak ahli etnografi mempelajari bagaimana pesan pesan komunikasi yang dilakukan atau dikomunikasikan dalam bentuk komunikasi non-verbal mampu menguraikan "sandi bahasa" yang ada. Ini artinya bahwa untuk memahami budaya yang berbeda perlu pola pola komunikasi dan proses pertukaran ide, gagasan, dan makna antara satu budaya dengan budaya yang lain.

Komunikasi dan kebudayaan bertalian erat secara resiprokal. Perhatian tipikal bidang komunikasi dan kebudayaan terletak pada cara bagaimana manusia melakukan komunikasi lintas manusia dan lintas kelompok sosial. Arah lintas komunikasi selalu menggunakan kodekode pesan, baik secara verbal maupun non-verbal yang secara alamiah selalu digunakan dalam semua konteks interaksi. Mengkaji studi komunikasi dan kebudayaan terdapat proses untuk dapat memahami 'makna' yang ada, 'pola-pola' tindakan dan bagaimana makna dan polapola itu diartikulasi dalam suatu kelompok sosial, kelompok budaya, kelompok politik, lingkungan pendidikan, dan lingkungan lainnya yang melibatkan interaksi antar manusia (Liliweri, 2007: 12). Ketika para anggota dalam sistem sosial masyarakat bisa saling berinteraksi maka pada saat yang bersamaan kebiasaan, nilai dan norma tersebut dapat dibagikan (sharing) antar mereka sehingga kebiasaan, nilai dan norma tersebut menjadi berkelindan dari para anggota sistem sosial tersebut. Yang menjadi permasalahan untuk didalami adalah bagaimana konsep dan teknis menjaga eksistensi budaya lokal dengan pendekatan komunikasi lintas budaya.

\section{LANDASAN TEORI \\ 2.1 Kajian Budaya Lokal}

Pada dasarnya setiap manusia terlahir ke dunia dibentuk dan dibesarkan dalam konstruk budaya yang spesifik, termasuk di dalamnya suatu proses internalisasi nilai dan norma budaya. Seseorang mempelajari dan menjalankan kaidah kaidah yang baik dan menghindari yang buruk karena proses internalisasi dalam budaya masyarakat yang sudah menjadi acuan dalam berpikir dan berperilaku. Misalnya, jika seseorang dibesarkan dalam budaya Jawa maka dia akan bertingkah laku in line dengan kaidah-kaidah yang ada di dalam budaya tersebut, demikian pula budaya yang lainnya. Upaya mengembangkan potensi budaya lokal maka peran komunikasi antar budaya harus dapat memahami kaidah kaidah nilai dan norma adat istiadat yang berlaku dalam budaya tersebut.

Budaya lokal mencakup norma, kebiasaan dan nilai bersama yang dianut secara dinamis oleh suatu masyarakat tertentu. Pengertian budaya lokal sering dikaitkan dengan kebudayaan suku bangsa. Konsep Suku bangsa sendiri sering diidentikkan dengan konsep kelompok etnik. Menurut Fredrik Barth sebagaimana yang dikutip oleh Suparlan bahwa suku bangsa hendaknya dilihat sebagai golongan atau sekelompok manusia yang khusus. Kekhususan suku bangsa diperoleh secara turun temurun dan melalui interaksi antar budaya dalan rentang sejarah yang panjang. Budaya Lokal, dalam konteks ini budaya suku bangsa, menjadi indentitas pribadi atau kelompok dalam suatu masyarakat. Ciriciri yang telah menjadi identitas budaya diri itu melekat sepanjang hidup sosialnya (Sutardi, 2007:11).

Menurut Zulyani Hidayah, terdapat lima ciri budaya suku bangsa yang dapat dijadikan sebagai referensi pensetaraan 
dengan budaya lokal, antara lain: pertama, adanya komunikasi melalui bahasa dan dialek di antara mereka. Kedua, pola-pola sosial kebudayaan yang menimbulkan perilaku sebagai bagian dari kehidupan adat istiadat yang dihormati bersama. Ketiga, adanya perasaan keterikatan antara satu dengan yang lainnya sebagai suatu kelompok bagian yang menimbulkan rasa kebersamaan diantara mereka. Keempat, adanya kecenderungan menggolongkan diri ke kelompok asli terutama ketika menghadapi kelompok lain pada berbagai kejadian sosial kebudayaan. Kelima, adanya perasaaan keterikatan dalam kelompok karena hubungan kekerabatan, genealogis dan ikatan kesadaran teritorial diantara mereka.

\subsection{Definisi Komunikasi}

\section{a. Istilah Komunikasi}

\section{Istilah}

komunikasi

(communication) berasal dari kata Latin "communicatus", artinya "berbagi" atau menjadi milik bersama. Komunikasi menurut para Lexicographer (ahli kamus bahasa) menunjuk pada suatu upaya yang memiliki tujuan berbagi untuk mencapai kebersamaan. Dalam Webster's New Collegiate Dictionary edisi tahun 1977, komunikasi adalah "suatu proses pertukaran informasi antar individu melalui sistem lambang-lambang, tandatanda atau tingkah laku.'(Djuarsa, 1993 :7). Sedangkan, Menurut Hovland, Janis \& Kelley, komunikasi adalah suatu proses melalui mana seseorang (komunikator) menyampaikan stimulus (biasanya dalam bentuk kata kata) dengan tujuan mengubah atau membentuk perilaku orang-orang lainnya (khalayak).

\section{b. Kajian Saundra Hybels dan Richard L.Weaver}

Komunikasi adalah setiap proses pertukaran informasi, gagasan dan perasaan. Proses itu meliputi informasi yang disampaikan tidak hanya secara lisan dan tulisan, tetapi juga dengan bahasa tubuh, gaya maupun penampilan diri atau menggunakan alat bantu disekeliling kita untuk memperkaya sebuah pesan (Liliweri,

2002 :3). Dari definisi para ahli komunikasi bahwa dinamika komunikasi merupakan langkah untuk memahami dan menganalisi keterlibatan kita dalam interaksi antar manusia. Lebih jauh, komunikasi juga merupakan proses mengenai pembentukan, penyampaian, penerimaan dan pengolahan pesan. Setiap pelaku komunikasi akan melakukan tindakan membentuk, menyampaikan, menerima dan mengolah pesan. Pesan ini dapat berupa pesan tertulis, lisan, gambar, gerak gerik atau tingkah laku serta berbagai bentuk tanda lainnya ( Djuarsa, 1993 : 9).

\section{c. Istilah Kebudayaan}

Dari asal kata, istilah kebudayaan bermula dari kata Sansekerta buddayah sebagai bentuk jamak dari buddhi yang berarti budi atau akal. Kebudayaan dapat diartikan sebagai "sesuatu yang berkaitan dengan budi atau akal". Bahasa Inggrisnya culture, dari bahasa Latin colere, memiliki pengertian mengolah, mengerjakan; atau, sebagai segala daya dan usaha manusia mengubah alam. Dari pengertian ini, definisi umum kebudayaan dapat dikatakan sebagai keseluruhan tata cara hidup suatu masyarakat. Melihat batasan ini, kebudayaan berarti mencakup semua cara berpikir dan berperilaku manusia, mulai dari hal yang sederhana sampai yang kompleks, yang menggunakan kekuatan cipta, rasa, dan karsa. Secara umum, kebudayaan adalah kehidupan manusia itu sendiri yang meliputi pikiran, karya dan hasil karyanya. Sedangkan, bagian atau sisi dari kebudayaan diartikan dengan sesuatu yang indah, seperti kesenian dengan berbagai bentuknya (Djuarsa, 1993:186).

Koentjaraningrat menjelaskan kebudayaan melingkupi konsep yang luas sehingga untuk kepentngan analisis teoritis, kebudayaan perlu dipilah lagi menjadi beberapa unsur. Unsur-unsur 
utama kebudayaan kemudian dipilah-pilah dan ditentukan pokok pokoknya, yang kemudian disebut sebagai unsur-unsur kebudayaan universil, yang itu semua ada di seluruh kebudayaan di dunia. Unsurunsur universal yang merupakan inti dari semua kebudayaan yang ada antara lain:

(1) Sistem religi dan upacara keaagamaan;

(2) Sistem dan organisasi kemasyarakatan;

(3) Sistem pengetahuan; (4) Bahasa; (5) Kesenian; (6) Sistem mata pencaharian hidup; dan (7) Sistem teknologi dan peralatan. Menurut Soemardjan dan Soemardi, kebudayaan merupakan semua hasil dari karya, rasa dan cipta masyarakat. Tidak ada suatu masyarakat dimana pun yang hidup tidak memiliki kebudayaan. (Soleman,1994 123).

\section{d. Istilah Komunikasi Lintas Budaya}

Komunikasi dan kebudayan seperti dua sisi mata uang yang resiprokal. Pusat perhatian komunikasi dan kebudayaan terletak pada variasi langkah dan cara manusia berkomunikasi melintasi komunitas manusia atau kelompok sosial. Para pelintas kebudayaan dan komunikasi, baik secara verbal maupun non-verbal secara alamiah selalu digunakan dalam konteks interaksi. Pusat studi tentang komunikasi dan kebudayaan juga meliputi bagaimana menjajaki makna-makna, polapola, tindakan dan bagaimana pula makna serta pola-pola itu diartikulasikan dalam sebuah kelompok sosial, kelompok budaya, kelompok politik, proses pendidikan bahkan lingkungan teknologi yang melibatkan interaksi lintas manusia. Rich dan.Ogawa menyatakan bahwa komunikasi lintas budaya adalah komunikasi antar orang-orang yang berbeda budayanya, yang menerobos lintasan suku bangsa, etnik, ras dan kelas sosial. Sementara menurut C.H.Dood, komunikasi lintas budaya melibatkan para komunikan yang mewakili pribadi, lintas pribadi, atau kelompok, dengan tekanan pada perbedaan latar belakang kebudayaan yang mempengaruhi perilaku komunikasi para komunikan (Liliweri, 2002 :12).

\section{METODOLOGI}

Kajian ini menggali secara kualitatif dari berbagai fenomena eksistensi budaya lokal, termasuk di dalamnya media bahasa lokal yang digunakannya sebagai alat komunikasi, baik verbal maupun nonverbal. Terus menerusnya penipisan survivalitas budaya lokal dan komunikasi bahasa lokal akibat reduksi globalisme mengakibatkan keterancaman eksistensinya dari waktu ke waktu. Dari kajian literatur yang cukup mendalam dalam tulisan ini, termasuk budaya lokal di Kabupaten Jember, yang dikenal sebagai budaya Pendhalungan, sebuah budaya hibrida, yang diwarnai oleh akulturasi budaya Jawa dan Madura, menjadikan kajian ini signifikan adanya.

Metode kajian pustaka secara kualitatif ini menulusuri secara teoritik buku buku dan jurnal ilmiah terakreditasi, mulai dari bukunya Koentjaraningrat tentang unsur unsur kebudayaan; Dimensi Manusia Dalam Pembangunan oleh Soedjatmoko; "Speech Codes Theory: Traces of Culture in Interpersonal Communication", dari Gerry Philipsen; "Makna Budaya dalam Komunikasi Antar Budaya' oleh Alo Liliweri; dan 'Orang Pendalungan: Penganyam Kebudayaan Di Tapal Kuda' oleh M. Ilham Zoebazary, serta beberapa Jurnal ilmiah lainnya. Kesahihan olah data yang dikaji mengindikasikan adanya korelasi positif antara eksistensi budaya lokal dan alat komunikasi berupa bahasa lokal memiliki resistensi yang kuat di dalam upaya melestarikannya.

\section{PEMBAHASAN}

Globalisme telah menggiring arah suatu arus besar budaya (cultural mainstream) menuju proses cultural values of mondiaism (mondialisasi nilai nilai budaya) dari satu lingkup ruang budaya ke ruang budaya lainnya. Proses penduniaan dari sebuah proses perubahan sosial yang cepat, secara masif dan akseleratif, didukung oleh teknologi komunikasi yang memungkinkan 
percepatan pertukaran pesan membobol lintas ruang dan waktu. Konsekwensi logisnya adalah bahwa pesan-pesan yang dikirimkan itu mengalami keberlimpahan dan distorsi (abundance and distorted) dari dan menuju ke sasaran penerima yang berbeda budayanya. Adalah Mc.Luhan yang menyatakan bahwa dunia akan menjadi desa global, dan memandang dunia hanya dalam satu dimensi budaya, yakni globalisme budaya. Dampak globalisme menjadikan dunia semakin sempit (global village), dimana interaksi antar bangsa di dunia mengalir deras setiap waktu. Manusia dari berbagai bangsa, etnis dan suku-suku dengan latar belakang nilainilai, adat-istiadat, ideologi, keyakinan yang berbeda, bertemu dan berkomunikasi satu sama lain dalam berbagai konteks, misalnya ekonomi, sosial, politik dan keamanan. Semestinya setiap bangsa harus memahami budaya bangsa lain dalam hubungan antar negara secara saling menguntungkan (reciprocality). Semua orang dalam aktivitasnya dilakukan melalui komunikasi. Komunikasi kebudayaan yang memiliki kesamaan karakteristik budayanya akan menjadi lebih mudah bersimbiosis karena adanya kesamaan dalam latar belakang pengalamanya sehingga tujuan komunikasinya lebih mudah tercapai.

Salah satu dari tujuh unsur kebudayaan dari Koentjaraningrat yang terus harus dijaga dan dikembangkan adalah unsur komunikasi lewat bahasa; selain dari unsur pengetahuan, mata pencaharian, adat istiadat, kesenian dan sistem peralatan hidup. Bahasa merupakan unsur kebudayaan yang bersifat nonmaterial, sarat dengan nilai, norma dan kepercayaan. Dalam dinamika komunikasi yang bersifat satu arah (moderen selalu benar, lokal selalu harus mengikuti), maka gerakan budaya dalam penggunaan bahasa lokal dan nasional, menjadi semakin penting. Bahasa sebagai alat komunikasi yang digunakan dalam semua suku bangsa terdiri dari pola kata kata dan simbolsimbol sehingga bahasa merupakan susunan berlapis dari simbol simbol yang ditata oleh para ahli bahasa. Bahasa lisan maupun tulisan sebagai bentuk dari komunikasi, mempunyai kode verbal dimana mengacu pada naskah, teks dan dalam praktiknya kita temukan dalam bentuk kata. Dalam upaya mengembangkan dan menjaga budaya lokal, ada keharusan bagi masyarakat itu menjaga bahasa lokal yang ada di daerahnya. Dalam bahasa Jawa mengenal undhak undhuk basa yang menjadi bagian integral dalam tata krama masyarakat Jawa. Di Yogjakarta dan Surakarta masih bertahan suatu bentuk bahasa bagongan dan kedhaton yang dipakai sebagai bahasa pengantar di lingkungan Keraton. Sebagaimana yang pembaca ketahui bahwa dalam bahasa Jawa terdapat tiga bentuk tingkatan berbahasa, yaitu ngoko ("kasar"), madya ("biasa"), dan krama ("halus"). Di antara masing-masing bentuk ini terdapat bentuk "penghormatan" (ngajengake, honorific) dan "perendahan" (ngasorake, humilific). Seseorang dapat berubah-ubah registernya pada suatu waktu tergantung status yang bersangkutan dan lawan bicara. Status bisa ditentukan oleh usia, posisi sosial, keturunan, atau hal-hal lainnya. Seorang anak yang bercakap-cakap dengan sebayanya akan berbicara dengan varian ngoko, namun ketika bercakap dengan orang tuanya akan menggunakan krama andhap dan krama inggil. Sistem semacam ini terutama dipakai di Surakarta, Yogyakarta, dan wilayah Jawa Timur Mataraman.

Penggunaan bahasa dalam upaya menjaga dan mengembangkan budaya lokal dalam pendekatan komunikasi lintas budaya, antara lain bisa dilakukan dengan cara :

1. Penguatan kesadaran pribadi. Setiap individu pada dasarnya mempunyai kepribadian, kecenderungan dan kebiasaan (tingkah laku) spesifik masing-masing. Kesadaran pribadi dimaksud adalah pribadi sebagai person tunggal dan sekaligus pribadi dalam konteks kolektif keluarga, bertetangga, 
dan berkebangsaan. Dalam keluarga kecil, lokalitas masyarakat, dan bangsa lumrah (natural) memiliki perbedaan perilaku budaya dan pluralitas kepribadian yang sering dialami. Meskipun demikian realitasnya, terjaganya dan tumbuhnya rasa saling menghargai, saling memahami keragaman perbedaan budaya akan tetap mempererat hubungan saling menguatkan. Ini artinya bahwa apabila ingin tetap mempertahankan budaya lokal, penguatan kesadaran pribadi menjadi hal yang sangat urgen.

2. Penguatan kesadaran domestik. Meskipun secara domestik bangsa Indonesia relatif belum berhasil (baca: gagal) membangunan kesadaran budaya bangsanya, namun dengan makin besarnya peluang setiap orang untuk berinteraksi dengan antar daerah lain yang memiliki kebudayaan yang berbeda, negara harus memberikan role model yang menyatukan dalam keinsafan budaya nasional.

3. Penguatan jejaring budaya mondial. Semakin canggihnya teknologi komunikasi dan informasi, pengaruh lintas bangsa pasti tidak terelakkan. Menguatkan budaya bangsa dengan berbagai keunggulan kompetitif dan keunggulan diferensiatif (competitive and differentiative advantages) kepada bangsa bangsa lain harus dibangun oleh negara (baca: pemerintah). Ada kewajiban bagi negara untuk terus menerus memupuk rasa bangga sebagai bangsa (sense of national pride) dan rasa memiliki (sense of belonging) terhadap kekhasan budaya bangsa sendiri.

\section{KESIMPULAN DAN SARAN}

1. Salah satu kunci menguatkan budaya lokal di era digital saat ini (era 4.0) adalah memahami dengan kearifan terhadap budaya sendiri. Jika masyarakat gegar budaya maka bangsa ini akan hanyut dalam kekalahan kompetisi dan pengaruh budaya mainstream. Bahasa komunikasi adalah alat penghubung dalam pergaulan lintas budaya di era globalisme.

2. Komunikasi lintas budaya, baik domestik maupun mondial, masyarakat lokal dengan budayanya harus diapresiasi oleh masyarakat pemiliknya sendiri. Bentuk bentuk apresiasinya adalah dengan penguatan komunikasi budaya dalam bingkai "may involve but not dissolve (bisa berbaur namun tidak melebur).

3. Negara, disini pemerintah, berkewajiban melakukan gerakan sadar budaya 'yang benar' secara masif kepada masyarakat, khususnya di dunia pendidikan. Kunci pentingnya adalah menguatkan gerakan budaya literasi kepada masyarakat secara well-planned dan demokratis.

\section{DAFTAR PUSTAKA}

Barthes, Roland (2014). "Semiotics". In Griffin, Em. A First Look at Communication Theory (9th ed.). McGraw-Hill. pp. 327-38.

Djuarsa, Sasa, 1993. Pengantar Ilmu Komunikasi. Universitas Terbuka Press, Jakarta

Gerry Philipsen, "Speech Codes Theory: Traces of Culture in Interpersonal Communication," CA, 2008, pp. 269-280.

Griffin, EM. 2000. Communication Theory, Mc Graw Hill, USA.

Hidayah, Zulyani. 2015. Ensiklopedi Suku Bangsa di Indonesia. Jakarta:

Hovland's work is also discussed in Arthur R. Cohen's Attitude Change and Social Influence (Basic Topics in Psychology) (1964).

Koentjaraningrat, 1971.,Manusia Dan

Kebudayaan di Indonesia.

Gramedia Press. Jakarta 
Liliweri, Alo, 2007. Makna Budaya dalam Komunikasi Antar Budaya, LKIS, Yogyakarta

Parsudi Suparlan, 2004. Hubungan Antar

Suku Bangsa, YPKIK. Jakarta

Richard Weaver's books Ideas Have

Consequences and The Ethics of Rhetoric 1985 (1953).

Saundra Hybels \& Richard L. Weaver, 2017. Communicating Effectively - 8th Edition. Boston, Mass.

McGraw-Hill.

Sutardi, Tedi, 2007. Antropologi Mengungkap Keragaman Budaya, PT. Setia Purna Invest, Bandung

Taneko, Soleman,1994. Sistem Sosial Indonesia, CV.Fajar Agung, Jakarta

Webster's Ninth New Collegiate

Dictionary pada tahun 1983. 